DOI: https://doi.org/10.47405/mjssh.v5i8.485

\begin{tabular}{|c|c|}
\hline III & Malaysian Journal of Social Sciences and Humanities (MJSSH) \\
\hline $\begin{array}{c}\text { Malaysian Journal of } \\
\text { socals }\end{array}$ & Volume 5, Issue 8, August 2020 \\
\hline (MN - SSH) & e-ISSN : 2504-8562 \\
\hline & $\begin{array}{l}\text { Journal home page: } \\
\text { www.msocialsciences.com }\end{array}$ \\
\hline
\end{tabular}

\title{
Warehouse Specification Proposition for Urbanis (Urban Farming Company) Using Discrete Event Simulation Method
}

\author{
Ali Aqsa1, Meditya Wasesa ${ }^{1}$ \\ ${ }^{1}$ School of Business and Management, Bandung Institute of Technology, Indonesia \\ Correspondence: Ali Aqsa (Ali_aqsa@sbm-itb.ac.id)
}

\begin{abstract}
Two percent of the world's surface use for cities, yet it consumes 75 percent of its resources. Urban farming is an emerging alternative food network that could supply some of the food needs in cities with less emission, healthier food, and the environment. Urbanis is a company that likes to contribute to the acceleration of urban farming, especially in Indonesia, by utilizing vacant land and labor. In 2021, Urbanis plans to scale up the production capacity to 10 tonnes per month or $400 \mathrm{~kg}$ per day. It requires us to have a warehouse to store the food product that has not been absorbed by the market. The purpose of this study is to find warehouse specifications for Urbanis and the amount of labor and rack inside the warehouse alongside capital and operational expenditure. This research uses a layout with an area of $5 \times 14$ meters for experimental design. The model then translated into a discrete-event simulation model named Anylogic. The results show, for each amount of arrival, the number of labor that utilizes effectively are two labors with a maximum number of rack 50. Given these results, the author conducted operational and capital expenditure, which consist of variable analysis and additional variables such as a table, fan, and chair. The result is Urbanis need Rp 50.738 .000 for capital expenditure while $\mathrm{Rp} 10.871 .337$ for operational expenditure.
\end{abstract}

Keywords: urban farming, warehouse specification, Urbanis

\section{Introduction}

Cities occupy only 2 percent of the world's surface, but they consume 75 percent of its resources (Girardet, 2008). In 2020 there are 154 million $(56,4 \%)$ out of 273 million living in the urban area (Worldmeter, 2020). Currently, food needs in Indonesia are being fulfilled by conventional local farms and imports.

Urban agriculture is a localized food system wherein the production, processing, distribution, access/consumption, and disposal/recycling of food occur in and around the city (Smit, Ratta and Nasr, 1996). According to Dr. Sam C. M. Hui (2011), urban farming or urban agriculture has a wide range of benefits such as environmental sustainability, social sustainability, and economic sustainability.

There have been many countries that used policy to encourage the use of urban farming. For example, in Japan, the local government requires the building owner to devote $20 \%$ of the rooftop to urban farming. In Singapore, the local government has a target to supply $25 \%$ of vegetables needed from urban farming. In the UK, low-carbon policies have made London people produce $18 \%$ of their nutrition from urban farming (Hui, 2011). 
DOI: https://doi.org/10.47405/mjssh.v5i8.485

There are three types of business model low-cost specialization, differentiation, and diversification. Low-cost specialization aims to produce high-added value food products with issues on transportation cost, freshness, and high perishability. Differentiation seeks to grow a niche or exotic as well as differentiate the production. Diversification aims to exploit urban farming outside selling the food itself; it could be recreational or education (Prados et al., 2017).

Meanwhile, according to Nasution (2015), the model that could be used on Urban Farming is Community Supported Agriculture (CSA). This model emphasizes the principles of risk-sharing, community building, and ecological (Vitari, 2018). In CSA, the majority of stakeholders could be divide into three segments; CSA organizer, members, and farmers (Empowerment Group). Here, urbanis position itself to be a CSA organizer.

Urbanis is choosing to adopt the CSA model on its business due to its connection with what urban farming offers, which are; sustainability and localization of food production. It is highly related to Urbanis vision to provide sustainable food through urban farming (Nasution, 2015).

Benchmarking to CSA pioneers in America, many companies conducted this model using membership payments for the community or members that want to join. This payment will allow them to get weekly/biweekly food produce from the farm (Harmon, 2014). To get higher productivity per farm, the farm needs to produce the food that has the highest productivity on each farm. As a CSA Organizer, Urbanis need to have the infrastructure to accommodate a variety of food products. In this case, Urbanis is planning to have its warehouse since it could become a place to store food meanwhile as a distribution center.

By then, this research will analyze the warehouses' specifications needed by Urbanis to accommodate the food produced.

\section{Previous Research on Food Logistics}

The food industry is becoming interconnected from farmer to customer. This relationship is called the Food Supply Chain Network (FSCN). There are 2 FSCN, fresh agriculture products, and processed food products. Fresh agricultural products are more vulnerable to the condition due to their freshness. Meanwhile, processed food products generally have been through a process that makes it hardly perishable (Vorst et al., 2009).

To deliver the product to the customer rightly, this requires the management of logistics in all nodes. Logistic management is a movement of goods to the customer with its objective to deliver the right product, in the right condition, with the right quality, in the right place, at the right time, and cost (Aghazadeh, 2004).

In research by Aghazadeh (2004), to make the food supply efficient, there should be a sharing of information electronically from the retail, distributor, and manufacturer. It helped all the chains could order or manufacture the "enough" amount of food, which led to a lower cost.

There are many KPI that could be used to see the effectiveness and efficiency of logistics. Table 1 KPI for logistics service provision. 
DOI: https://doi.org/10.47405/mjssh.v5i8.485

Table 1: Performance indicators for logistics service provision

\begin{tabular}{|c|c|c|}
\hline \multicolumn{3}{|c|}{ Internal perspective - Management point of view } \\
\hline Revenue $\uparrow$ & Total number of orders $\uparrow$ & Long term plans availability / development $\uparrow$ \\
\hline Profit margins $\uparrow$ & Number of customers $\uparrow$ & Market share width $\uparrow$ \\
\hline Capacity utilization $\uparrow$ & Number of new customers $\uparrow$ & Number of markets that have been penetrated $\uparrow$ \\
\hline $\mathrm{Km}$ per day $\uparrow$ & Number of regular customers $\uparrow$ & Successful contacts - \% of successful deals out of the initial \\
\hline Labour productivity $\uparrow$ & Number of profitable customers $\uparrow$ & offers $\uparrow$ \\
\hline Price $\uparrow$ & Continuous improvement, rate $\uparrow$ & Effectiveness of distribution planning schedule $\uparrow$ \\
\hline Turnover per $\mathrm{km} \uparrow$ & Product range $\uparrow$ & $\%$ of orders scheduled to customer request $\uparrow$ \\
\hline Number of deliveries $\uparrow$ & Plan fulfilment $\uparrow$ & $\%$ of supplier contracts negotiated meeting target terms and \\
\hline Benefit per delivery $\uparrow$ & Total loading capacity (for trucks) $\uparrow$ & conditions for quality, delivery, flexibility and cost $\uparrow$ \\
\hline Trips per period $\uparrow$ & On-time delivery performance $\uparrow$ & Competitive advantage $\uparrow$ \\
\hline Perfect order fulfilment $\uparrow$ & $*$ Product variety $\uparrow$ & Certification (ISO 9001/9002, SQAS, HACCP) $\uparrow$ \\
\hline *Storage surface $\uparrow$ & ${ }^{*}$ Amount of products* $\uparrow$ & *Dangerous item storage possibilities $\uparrow$ \\
\hline *Storage volume $\uparrow$ & *Seperation of storage areas $\uparrow$ & ${ }^{*}$ Temperature control $\uparrow$ \\
\hline *Storage racks $\uparrow$ & *Handling equipment (electric, gas and & *Distance to highway $\downarrow$ \\
\hline *Number and characteristics & diesel/petrol forklifts) $\uparrow$ & $*$ Distance to train $\downarrow$ \\
\hline of docks $\uparrow$ & *Ventilation control $\uparrow$ & *Distance to waterway connection $\downarrow$ \\
\hline \multicolumn{3}{|l|}{ Efficiency } \\
\hline Total distribution cost $\downarrow$ & Average fuel use per $\mathrm{km} \downarrow$ & Overhead/management/administrative costs $\downarrow$ \\
\hline Labour utilization $\uparrow$ & Average delivery re-planning time $\downarrow$ & Quality of delivery documentation per truck/driver $\uparrow$ \\
\hline Overhead percentage $\downarrow$ & Marketing costs $\downarrow$ & Effectiveness of delivery invoice methods $\uparrow$ \\
\hline Overtime hours $\downarrow$ & Failure costs $\downarrow$ & $\%$ orders / lines received with correct shipping documents $\uparrow$ \\
\hline \% Absent employees $\downarrow$ & Prevention costs $\downarrow$ & \% product transferred without transaction errors $\uparrow$ \\
\hline Salaries and benefits $\downarrow$ & Appraisal/Inspection costs $\downarrow$ & Item/Product/Grade changeover time $\downarrow$ \\
\hline Controllable expenses $\downarrow$ & $\%$ of failed orders $\downarrow$ & Order management costs $\downarrow$ \\
\hline Non-controllable expenses $\downarrow$ & $\%$ of realized $\mathrm{km}$ out of planned $\mathrm{km} \uparrow$ & Supply chain finance costs $\downarrow$ \\
\hline Customer service costs $\downarrow$ & Performance measurements costs $\downarrow$ & Total supply chain costs $\downarrow$ \\
\hline Order management costs $\downarrow$ & Human resource costs $\downarrow$ & Total time in repair (for trucks) $\downarrow$ \\
\hline Inventories $\downarrow$ & Variable asset costs $\downarrow$ & Ratio of realized orders vs. requested orders $\uparrow$ \\
\hline Number of trucks in use $\uparrow$ & Fixed asset costs $\downarrow$ & Average delivery planning time $\downarrow$ \\
\hline $\begin{array}{l}\text { Total delivery costs } \downarrow \\
\text { *Pallets per hour } \downarrow\end{array}$ & Information system costs $\downarrow$ & *Pallets/ $\mathrm{m}^{2} \uparrow$ \\
\hline \multicolumn{3}{|l|}{ Satisfaction } \\
\hline Attrition of drivers $\downarrow$ & On-time delivery performance $\uparrow$ & $\%$ of orders scheduled to customer request $\uparrow$ \\
\hline Morale, motivation of & Number of customer complains $\downarrow$ & Overall employees satisfaction $\uparrow$ \\
\hline personnel $\uparrow$ & Overall customer satisfaction $\uparrow$ & Overall society satisfaction $\uparrow$ \\
\hline \multicolumn{3}{|l|}{ IT and innovation } \\
\hline Information system costs $\downarrow$ & Number of new products in the range $\uparrow$ & $\%$ of information management assets used / production \\
\hline Up-to-date performance & $\%$ of information exchange through IT $\uparrow$ & assets $\uparrow$ \\
\hline information availability $\uparrow$ & $\%$ of employees with IT training $\uparrow$ & $\%$ of invoice receipts and payments generated via EDI $\uparrow$ \\
\hline Utilization of IT equipment $\uparrow$ & Availability of IT equipment $\uparrow$ & Average time for new products development $\downarrow$ \\
\hline IT training costs $\downarrow$ & Use of RFID/Barcoding $\uparrow$ & Average costs for new product development $\downarrow$ \\
\hline \multicolumn{3}{|c|}{ Internal perspective - Employee's point of view } \\
\hline $\begin{array}{l}\text { Km per trip } \downarrow \\
\text { Working conditions } \uparrow\end{array}$ & Weight to (un)load per labour hour $\downarrow$ & Salaries and benefits $\uparrow$ \\
\hline \multicolumn{3}{|c|}{ External perspective - Customer's point of view } \\
\hline Transportation price $\downarrow$ & Transparency for a customer $\uparrow$ & Services variety $\uparrow$ \\
\hline Insurance price $\downarrow$ & Possible types of communication $\uparrow$ & Order configuration flexibility $\uparrow$ \\
\hline Primary services price $\downarrow$ & Available types of goods insurance $\uparrow$ & Possibility to change order details $\uparrow$ \\
\hline Goods safety $\uparrow$ & Order size flexibility $\uparrow$ & Additional services price (priority transportation) $\downarrow$ \\
\hline Product variety $\uparrow$ & Timeliness of goods delivery $\downarrow$ & Contact points (number of people to contact) $\downarrow$ \\
\hline Response time $\downarrow$ & *Duration pickup until information is & *Assistance with customs $\uparrow$ \\
\hline *Opening hours $\uparrow$ & updated inventory information is & \\
\hline${ }^{*}$ On site offices $\uparrow$ & available to shipper $\downarrow$ & \\
\hline \multicolumn{3}{|c|}{ External perspective - Society's point of view: } \\
\hline Level of $\mathrm{CO} 2$ emission $\downarrow$ & Solid particles emission $\downarrow$ & Competition level among similar companies $\uparrow$ \\
\hline Society satisfaction $\uparrow$ & Taxes to the national treasury $\uparrow$ & Care for animals/children around $\uparrow$ \\
\hline Wasting resources $\downarrow$ & Participation in charitable actions $\uparrow$ & Use of innovation technologies $\uparrow$ \\
\hline Recycling level $\downarrow$ & Reputation of a company $\uparrow$ & Development of innovation technologies $\uparrow$ \\
\hline Employees satisfaction $\uparrow$ & Road maintenance costs $\downarrow$ & Cooperation with other companies $\uparrow$ \\
\hline Disaster risk $\downarrow$ & Number of available work places $\uparrow$ & \\
\hline
\end{tabular}

(Source: Krauth, et al., 2005)

\section{Food Warehouse Simulation}

Inventory cost could be as high as $50 \%$ of the purchase cost in many companies (Hodson, 1992). Thus, many companies are trying to be as efficient as possible in storing material or products in the warehouse.

Food warehouses have different challenges compared to other products. Food is a perishable product that requires special treatment such as temperature control, freshness date, and many more. Failure to 
DOI: https://doi.org/10.47405/mjssh.v5i8.485

provide this gives risk to the product and will be waste due to the quality (Stragas \& Zeimpekis, Unknown).

There are many types of food warehouses; cross-docking, 3PL, and private or lease warehouses. This type of warehouse has its function - See table 2.

Table 2: Type of Warehouse Function

\begin{tabular}{|c|c|c|}
\hline Cross-Docking & 3PL & $\begin{array}{l}\text { Private or leased } \\
\text { warehouses }\end{array}$ \\
\hline No intermediate storage & $\begin{array}{l}\text { Provision of warehouse } \\
\text { services for a third party }\end{array}$ & $\begin{array}{l}\text { Most commonly warehouse type } \\
\text { used }\end{array}$ \\
\hline Batches cut into smaller & Low investment costs & $\begin{array}{l}\text { Usually established nearby the } \\
\text { company's property }\end{array}$ \\
\hline Goods are mixed & Saving human resources & Serve specific needs \\
\hline Orders completion & Saving financial resources & $\begin{array}{l}\text { Management conducted by the } \\
\text { company }\end{array}$ \\
\hline Goods loaded and shipped & Include indoor procedures & $\begin{array}{l}\text { Management know-how } \\
\text { required }\end{array}$ \\
\hline
\end{tabular}

There are many KPI to measure the efficiency of the warehouse. Previous articles have been write regarding the use of simulation as a tool in warehouse design (Senko and Suskind, 1990). More examples were written of articles discussing models of order picking systems (Daniels et al . 1998, Kim et al . 2002), cost models for inventory and inventory sizing models (Cormier and Gunn 1996), warehouse capacity expansion models (Cormier and Gunn 1999), storage allocation (Macro and Salmi, 2002).

One of the most common methods of analyzing warehouse operations has historically been a simulation. Through seminal work on the simulation ability in warehouse management (see, for example, Bafna, 1973 and Biles 1977) to recent publications, the simulation was mainly used to validate the efficiency of warehouse structures or material handling equipment.

\section{Order Picking}

In the internal distribution center operation, order picking could occupy up to $50 \%$ of the overall cost (Hsieh \& Tsai, 2006). In order to minimize the cost, four typical strategies could be used. They are (1) layout design, (2) picking policies, (3) storage assignment policies, and (4) routing policies (Chan \& Chan, 2010).

According to Ashayeri (1985), the warehouse layout design goal is minimum building cost or material handling. Meanwhile, storage assignment policies aim to reduce travel time. Generally, the storage assignment policies are as follows: random storage, classified storage, fixed storage, volume-based storage, etc. (Hsieh \& Tsai, 2006). On the other hand, routing goals are to reduce unnecessary routes of picking orders. Lastly, picking policies determined how the order would be grouped (Chan \& Chan, 2010).

According to Krauth (2016), one of the warehouse's measurements is labor utilization and fixed asset costs. For labor utilization, a success indicator of labor utilization could see if the utilization is going up. In contrast, the fixed asset cost measurement will be a success if it's going down. Hence, this research will be focusing on the measurement of labor utilization and fixed cost (rack and building).

\section{Methodology}

The method used in this research is the discrete-event simulation. The research will use the framework suggested by Banks (2014) in figure 1. 
Figure 1: Steps in Simulation Study

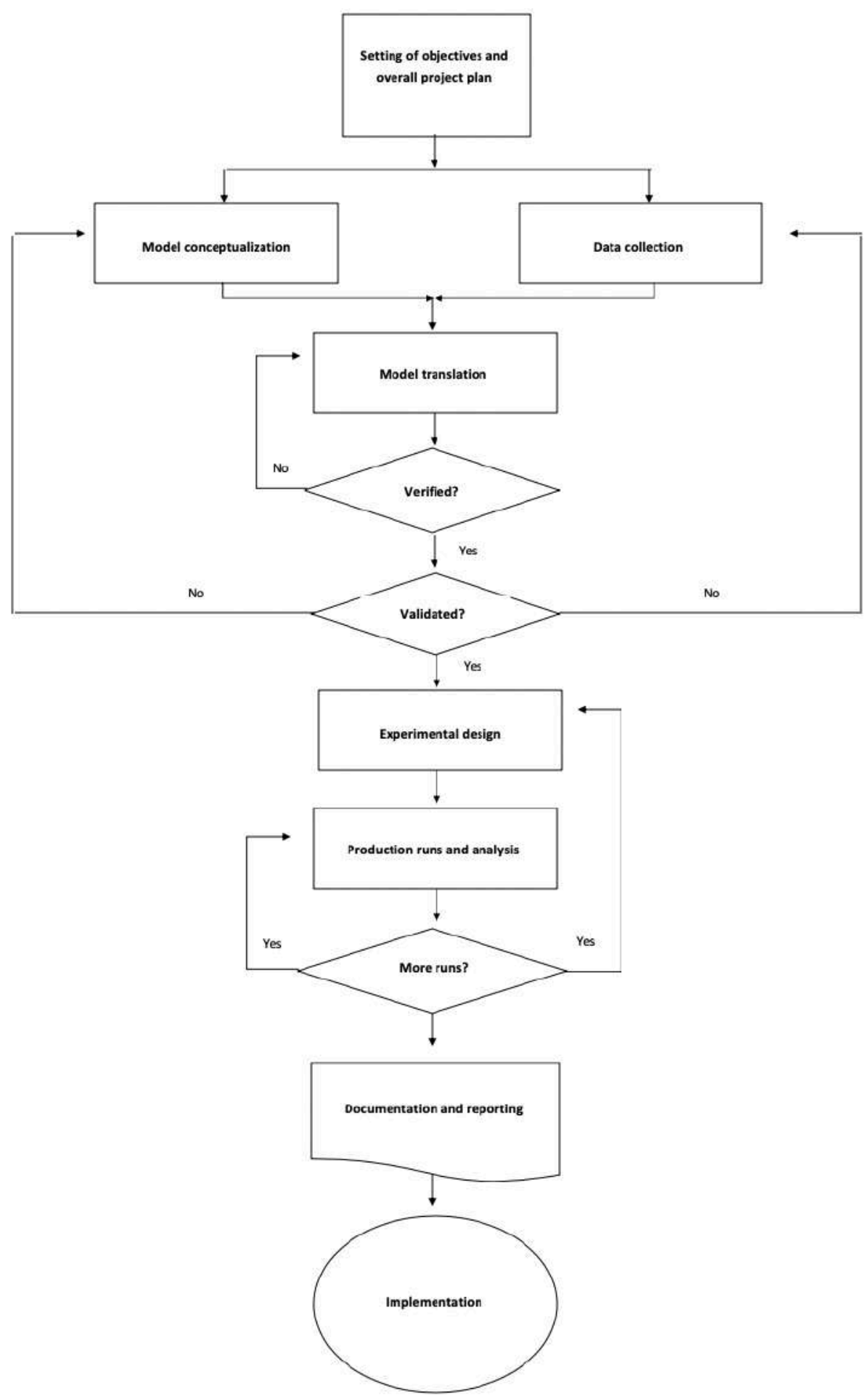

(Source: Banks, J. et al., 2014)

\section{Problem Formulation}

In early 2021, Urbanis will increase its production capacity up to 20 times its current capacity. Aside from that, the market will shift into community-supported agriculture (CSA), which will change the business model into subscription healthy food production. Due to various types of food products, the companies need to have a place where it can store and combine the food produce. These necessities 
DOI: https://doi.org/10.47405/mjssh.v5i8.485

could be done in the warehouse. With high investment up front to make a warehouse, the company decided to measure the layout, consisting of the amount of rack and the utilization of labor.

\section{Setting of Objective and Overall Project Plans}

This research aims to find the amount of rack used by the companies when the production capacity increases. Meanwhile, it also measures the utilization of labor that works to store and prepare the food produced. From this measurement, then, the author will give the estimation of capital and operational expenditure that the company will be planned.

\section{Model Conceptualization}

The model will start with the truck coming to the warehouse. The supplier will unload the food products into the unloading area, from the truck, which will then be seized by the labor to put in the rack area. While putting in the rack area, the labor will then wait for the order.

After the order is received, the labor will collect the food products to be combined and packed. Then, it waited for the courier to come to the warehouse to bring the food products to the customer.

\section{Data Collection}

This research will use a quantitative approach to answering the problem. The data collected on this research will vary, ranging in observations, secondary data, and primary data (internal company data). In this research, the observations data will be the speed of pick-up car, labor, courier, and how many kgs could be brought per order by the courier.

The observation data will be collected by observing the speed of pick-up car, labor, courier, and how many kgs could be brought per order by the courier. Aside from that, it will also be strengthened by interviewing people who already work in similar situations.

Table 3: Interview

\begin{tabular}{ll}
\hline M. Faza Zharfan & CEO of Urbanis \\
Ryan & Head of Logistic in Harvest Supply \\
\hline
\end{tabular}

Secondary data will be pick-up car size, labor size, motorcycle size, and box size. The secondary data will be collected from official website companies or third party commerce such as tokopedia and rumah123. Lastly, primary data collected from internal companies data, which is the future projection of production capacity and schedule of food produce arrival per day in the warehouse.

\section{Model Translation}

Because most real-world programs result in models needing much information storage and computation, the model must be entered in a computer-recognizable format. In this research, the model will be computerized using a discrete-event simulation software application. The author chose Anylogic since this software is used by some Fortune 500 companies.

\section{Verified}

Verification applies to the simulation model. Will the machine system run properly? Since it is challenging, if not impossible, to effectively turn a concept into its model without any testing. When the functional and feedback parameters. The system structure is described correctly on the machine, and verification is done. 


\section{Validated}

Validation is the determination that a model represents the actual system accurately. Validation is typically accomplished by model validation, an iterative method that matches the model against real system actions and utilizes the inconsistencies between the two against refinement of the model and the observations obtained. This cycle is replicated before the consistency of the model is considered appropriate.

\section{Experimental Design}

In this research, the model will have six scenarios. This scenario differs in the supplies arriving in the warehouse and the amount of labor working inside the warehouse. From these differences, the author will then choose one scenario suitable for Urbanis in case of the maximum amount of equipment (rack) and average utilization of labor.

\section{Production runs and analysis}

The analysis of the simulation will measure the performance that has been selected in the research objective. In this research, two performances should be measured, maximum rack, and utilization of labor. After collecting the data from 6 scenarios, the researcher will choose which is the most suitable one.

\section{More runs?}

Based on the analysis of completed runs, the analyst will determine if additional runs are needed and how those additional experiments should be designed.

\section{Documentation and Reporting}

After the simulation has been done, the researcher will make a documentation of the program and progress that will be put on this research. This documentation will consist of the maximum amount of rack used, the average utilization of labor, and total product shipped monthly.

\section{Implementation}

Lastly, the researcher in this research in which management of the company will make the implementation plan according to the analysis of the simulation. The implementation will consist of the company's timeline and resources to implement the business solution suggested by this research.

\section{Model Conceptualization}

The flow chart of the simulation will start with the pick-up car coming with the food produced. Then, it unloads all the food produced into an unloading area, which will then be loaded to the rack by the labor inside the warehouse. After it is loaded, the labor then waits for the order by the customer. After the order is received, the labor then brings the food products to the packing station to be prepared. Lastly, the order produced will then be given to the courier who will ship it to the customer. 
Figure 2: Urbanis Model Conceptualization

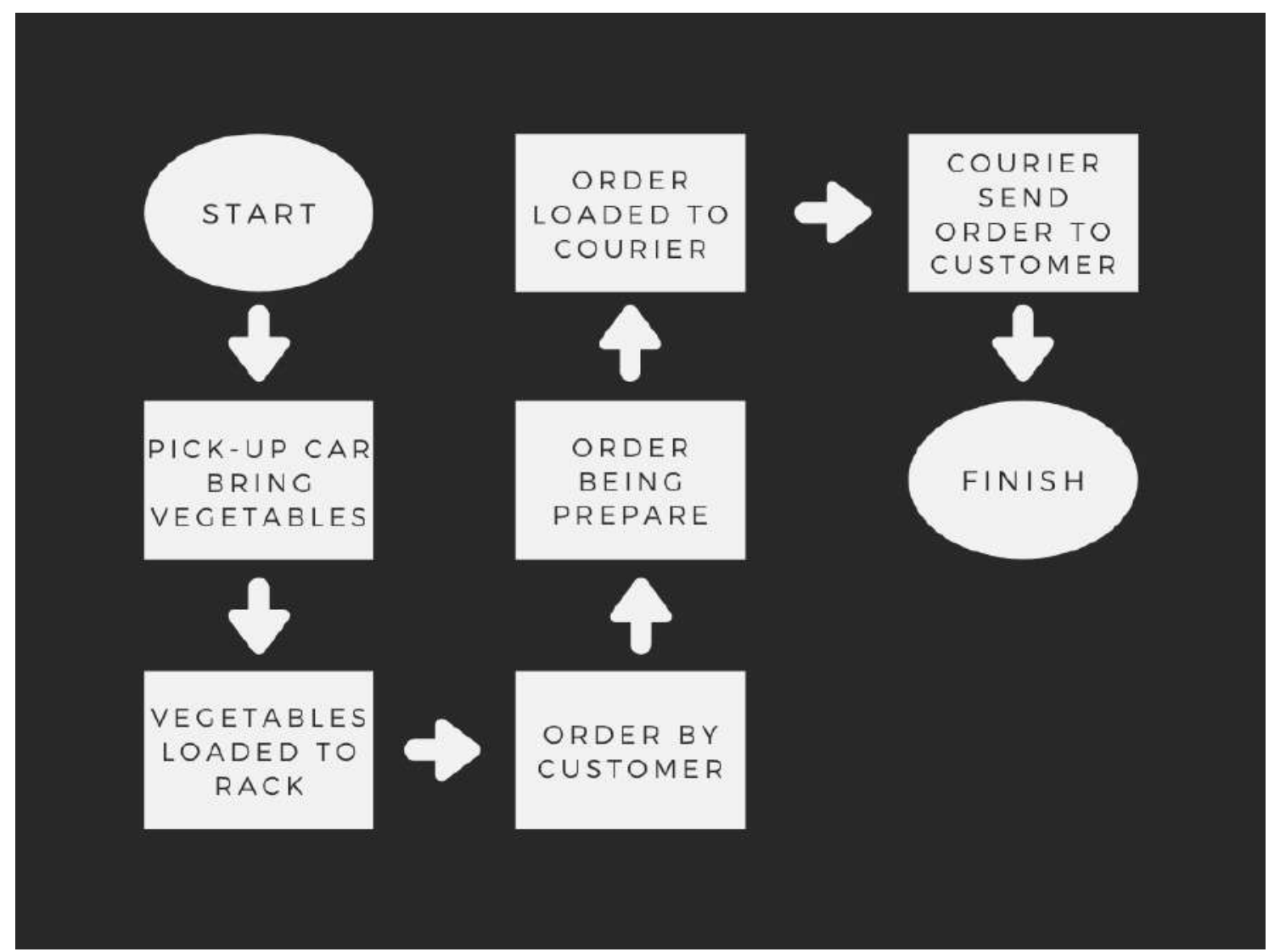

\section{Layout Design}

In this research, researchers will experiment with a layout with a total length and width of 14 and 5 meters, respectively. In front of the building, there will be parking space totaling $10 \mathrm{~m} 2(2 \times 5 \mathrm{~m})$. Inside the building, there will be three areas; unloading area $(2,5 \times 2 \mathrm{~m})$, packing and loading area $(2,5 \times 2 \mathrm{~m})$, and rack area $(5 \times 8 \mathrm{~m})$. The rack area will then be divide into two categories based on the food produced; bok choy and water spinach. The rack could be level up to 3 levels, with each linear rack could store up to 60 boxes. In each rack, it will have an aisle with a width of 1,3 meters.

Figure 3: Layout Design

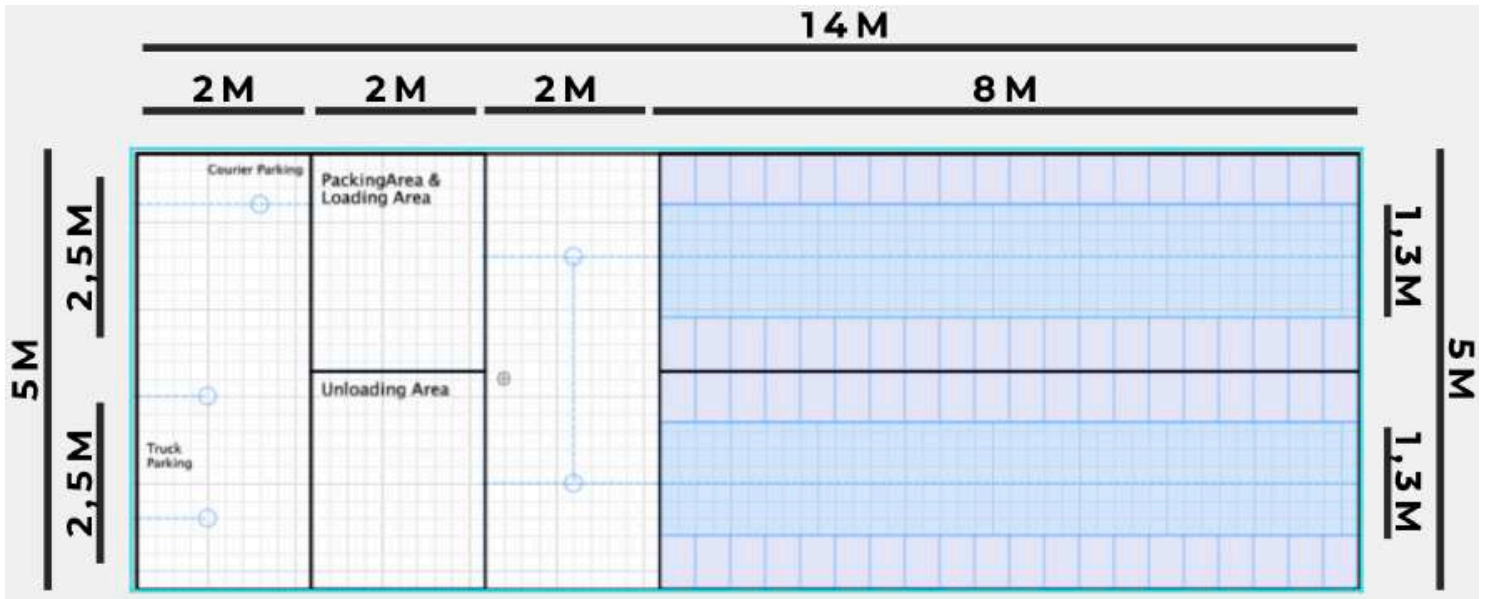




\section{Data Collection}

\section{Future Projection}

\section{Production capacity}

Future projection of the production capacity of urbanis warehouses will be divide into two scenarios. The first scenario will start in the first quarter of 2021, which will use total production capacity (8 tonnes/month) that partnered with DISPANGTAN. In the second quarter, we will add the production capacity with the Rumah Sakit Jiwa Provinsi Jabar, which will add up to 2 tonnes per site.

Table 4: Amount of food produce per month

\begin{tabular}{ll}
\hline 1st quarter of 2021 & 8 tonnes/ month \\
2nd quarter of 2021 & 10 tonnes/ month \\
\hline
\end{tabular}

The amount of food arrive at the warehouse will be the division between total production and the average number of working days ( 6 days per week) per month ( 25 days) which estimated will be:

Table 5: Amount of food produce per day

\begin{tabular}{ll}
\hline 1 st quarter of 2021 & $320 \mathrm{~kg} /$ day \\
2nd quarter of 2021 & $400 \mathrm{~kg} /$ day \\
\hline
\end{tabular}

The proportion of the food produced will be $50 \%$ each, which will be scheduled to be received $50 \%$ at 9 A.M. and 12 P.M on the working day (Monday - Saturday).

Table 6: Schedule of food supply

\begin{tabular}{lll}
\hline & 9 A.M. & 12 P.M. \\
1 st quarter of 2021 & $160 \mathrm{~kg}$ & $160 \mathrm{~kg}$ \\
2nd quarter of 2021 & $200 \mathrm{~kg}$ & $200 \mathrm{~kg}$ \\
\hline
\end{tabular}

\section{Market}

As our company is planning to focus on Community Supported Agriculture (CSA) using a membership model, there will be a significant change in the percentage of food produced being absorbed by each channel. The strategic management projection will be:

Table 7: Market Proportion

\begin{tabular}{ll}
\hline \multicolumn{1}{c}{ Selling Channel } & \multicolumn{1}{c}{ Percentage } \\
\hline B2B (Restaurant, catering, cafe, and etc) & $25 \%$ \\
B2C / CSA (Social Media) & $60 \%$ \\
\hline
\end{tabular}


As our members will mostly be people who are interested in sustainable products, most of the B2C market will be people who have middle-high income. The amount of product shipped by Urbanis will be linear to the amount of food available in the warehouse.

\section{Secondary Data}

The secondary data is collected in the retail price of plastic rack and minimum wages in Bandung (Upah Minimum Kota Bandung). The plastic rack's retail price will be collected via e-commerce, while minimum wages in Bandung will be referred to as Surat Edaran Nomor: 561/75/Yanbangsos. The price and wages will be shown in table 8 .

Table 8: Price and wages

$\begin{array}{ll}\text { Plastic Rack } & \text { Rp 84.500 / rack } \\ \text { Minimum Salary in Bandung } & \text { Rp 3.623.778,91/month }\end{array}$

Meanwhile, the size of the agent (labor, pick-up car, courier (motorcycle), and box) will be collected by looking at the official site or third-party commerce such as tokopedia. The size of the stakeholders will be in table 9 .

Table 9: Size of agent in the warehouse

\begin{tabular}{lcc}
\hline & Width (in cm) & Length (in cm) \\
\hline Labour & 60 & 15 \\
Pick-up Car & 150 & 240 \\
Courier (motorcycle) & 70 & 180 \\
Box & 40 & 60 \\
\hline
\end{tabular}

\section{Observational Data}

Observational data collected will be the speed of the agent in the warehouse, labor, pick-up car, and courier. This data collected by observing the agent then strengthens by interviewing people who work or have responsibilities in similar situations, such as Faza and Ryan, as CEO of Urbanis and Head of Logistics in Harvest Supply, respectively.

Table 10: Speed of agent in the warehouse

\begin{tabular}{lc}
\hline & Speed $(\mathrm{Km} / \mathrm{H})$ \\
\hline Labour & 2 \\
Pick-up Car & 2 \\
Courier (motorcycle) & 2 \\
\hline
\end{tabular}




\section{Model Translation}

The conceptual model then translated into a simulation software application named Anylogic. In this model, the researcher mimics the real-world event based on the previous part's data.

Figure 4: Business Translation

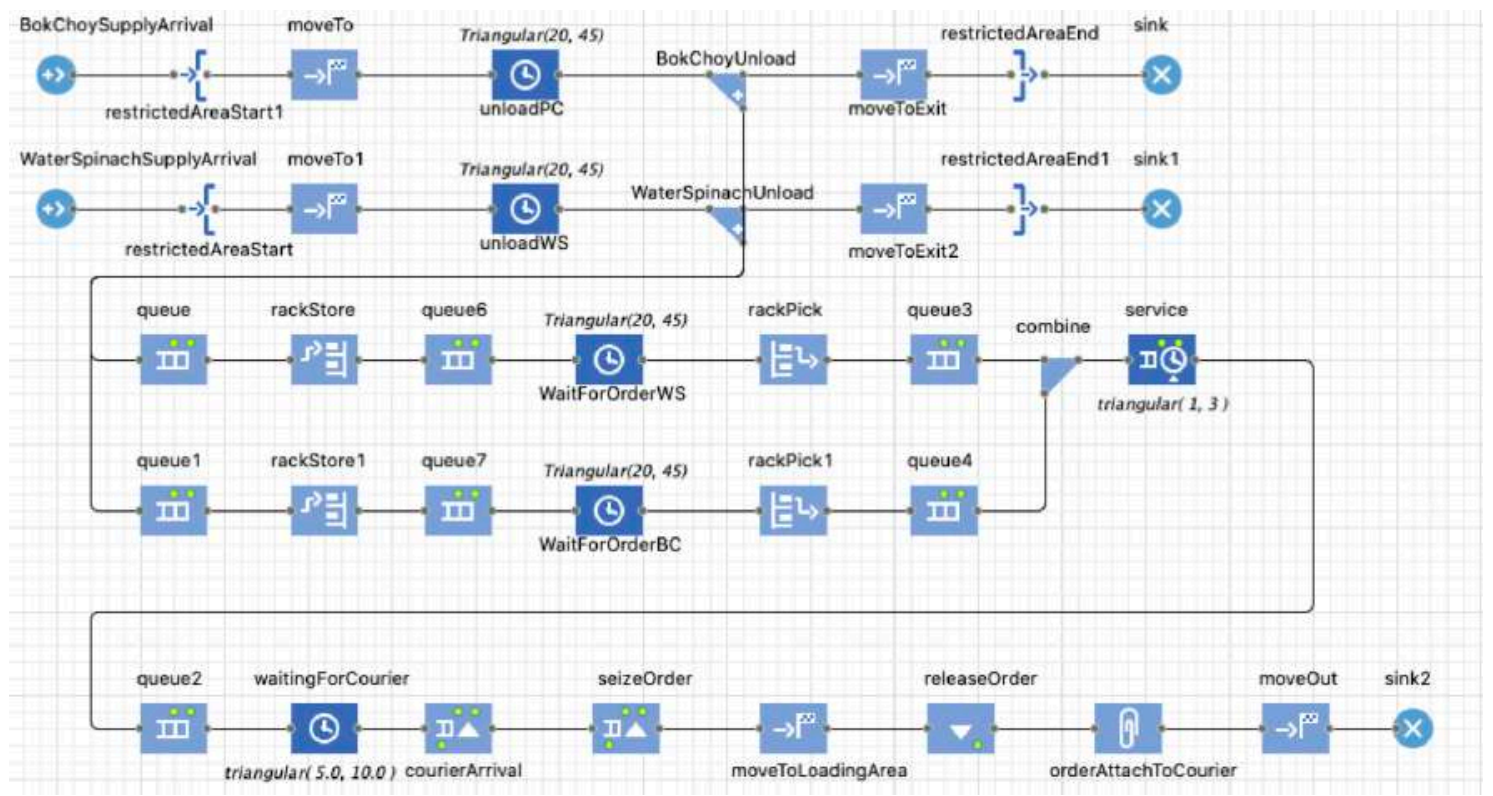

While testing in the simulation software, Anylogic, this model is verified to run well. Aside from that, this model is also validated to mimic real-world events inside the warehouse. Hence, this model could be used to simulate the Urbanis warehouse.

\section{Experimental Design}

In the 1st quarter and 2nd quarter of 2021, there will be three scenarios conducted for each quarter. Each quarter, the scenarios will be the amount of food arrive per schedule (Table 11) and the labor that works inside the warehouse. All the scenarios will be shown in Table 11.

Table 11: Experimental Design Scenario

\begin{tabular}{ll}
\hline $\begin{array}{c}\text { 1st quarter } \\
(320 \mathrm{~kg} \text { of food arrive each day })\end{array}$ & 1 labour \\
& 2 labour \\
$\begin{array}{c}\text { 2nd quarter } \\
(400 \mathrm{~kg} \text { of food arrive each day })\end{array}$ & 1 labour \\
& 2 labour \\
& 3 labour
\end{tabular}


DOI: https://doi.org/10.47405/mjssh.v5i8.485

\section{Documentation and Reporting}

From the simulation conducted, the data shown for each scenario will be shown in table 12 and 13 .

Table 12: Simulation results 1st quarter

\begin{tabular}{llll}
\hline & $\begin{array}{l}\text { Maximum Rack Used } \\
\text { in a month }\end{array}$ & $\begin{array}{l}\text { Average Labor } \\
\text { Utilization / month }\end{array}$ & $\begin{array}{l}\text { Total Product Shipped in a } \\
\text { month (26 days) }\end{array}$ \\
\hline $\begin{array}{l}1 \\
\text { Labour }\end{array}$ & $\begin{array}{l}\text { Water Spinach Rack } \\
\text { Full at day } 8\end{array}$ & 0.932 & $240 \mathrm{~kg}$ \\
2 & 32 & 0.717 & 8,32 tonnes \\
Labour & & 0,48 & 8,32 tonnes \\
3 & 33 & & \\
\hline
\end{tabular}

Table 13: Simulation results 2nd quarter

\begin{tabular}{llll}
\hline & $\begin{array}{l}\text { Maximum Rack Used } \\
\text { in a month }\end{array}$ & $\begin{array}{l}\text { Average Labor } \\
\text { Utilization / month }\end{array}$ & $\begin{array}{l}\text { Total Product Shipped in a } \\
\text { month (26 days) }\end{array}$ \\
\hline $\begin{array}{l}\text { Labour } \\
\text { at day 6 }\end{array}$ & $\begin{array}{l}\text { Bok Choy Rack Full } \\
2\end{array}$ & 0,906 & $80 \mathrm{~kg}$ \\
Labour & 50 & 0,914 & 10,28 tonnes \\
3 & 46 & 0.614 & 10,36 tonnes \\
Labour & & & \\
\hline
\end{tabular}

\section{Analysis}

Based on the data collected, it will then be calculated by using the average cost per $\mathrm{kg}$ for each scenario. Since in scenario 1, the rack reached full capacity and could not keep up to manage upcoming supply for the next day, by then, it was eliminated from the option. Table 14. below is the analysis for the cost.

Table 14: Analysis of labour cost per product

\begin{tabular}{llll}
\hline & Wages (A) & Total Product Shipped in a month in kg (B) & A/B \\
\hline 1st Q, 2 Labour & Rp 7,247,558 & 8320 & Rp871 \\
1st Q, 3 Labour & Rp 10,871,337 & 8320 & Rp1,307 \\
2nd Q, 2 Labour & Rp 7,247,558 & 10280 & Rp705 \\
2nd Q, 3 Labour & Rp 10,871,337 & 10360 & Rp1,049 \\
\hline
\end{tabular}

As the results show that, the least cost by each quarter is using two labors. Therefore, the author suggested using two labors for both the 1 st quarter and 2 nd quarter. 


\section{Warehouse Specification}

\section{Building}

For warehouse purposes, the author suggested finding a building that fits the amount of rack needed by the warehouse. Based on Rumah123.com, rent for the building is to pay for a minimum yearly. For this reason, we used the maximum amount of rack used in the 2 nd quarter since it has a higher amount.

In the second quarter, the amount of rack needed will be in total is 50. Divided into three levels of rack, the amount of size that needed by the company will be 16,67 rack or rounded to 17 racks. With this amount, the size for the rack only will need around $40,8 \mathrm{~m} 2$.

Gathering the data from Rumah123.com, the researcher suggested one suitable place that could be used by the company.

Figure 5: Building Suggestion

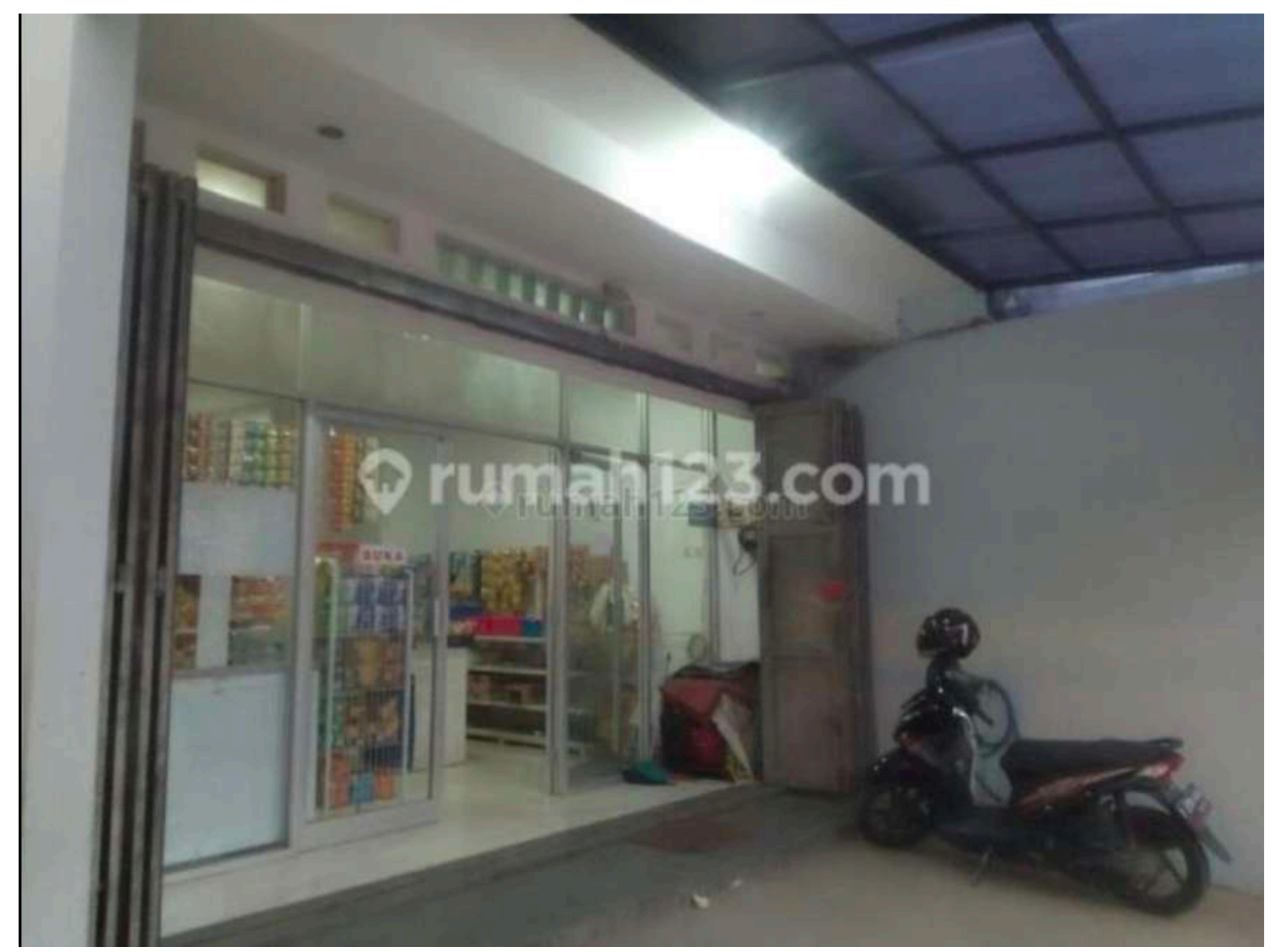

In the figure above, the building will have a total surface area of $100 \mathrm{~m} 2$, with a total building area of $95 \mathrm{~m} 2$. The area's length and width are $5 \times 20 \mathrm{~m}$, which is larger than the layout conducted in the simulation. In rumah123.com, the yearly rent for the building is $\mathrm{Rp} 45.000 .000 /$ year.

By having a larger area, this building could become a warehouse and office space for Urbanis. Meanwhile, the left area could also become the input space in the model, such as the toilet.

\section{Additional Warehouse Equipment}

There is a lot of material that needs to be in the warehouse yet not measured in the simulation. Such as a chair for the labor to sit or take a rest. 
DOI: https://doi.org/10.47405/mjssh.v5i8.485

Table 3.15: Additional Warehouse Equipment

\begin{tabular}{ll}
\hline Material & Qty \\
\hline Table & 3 \\
Chair & 5 \\
Fan & 2 \\
\hline
\end{tabular}

The table will be used for multi-purpose purposes such as packing, eating tables, etc. Meanwhile, chairs will be used for labor, courier, and supply to take a rest. Lastly, the fan is used to make sure the place is well ventilated.

\section{Additional Warehouse Human Resource}

With labor focus on the hard work inside the warehouse, there is a need to have people manage the warehouse data. Aside from that, this person will be responsible for supervising the labor while receiving guests. Hence, the company hypothetically needs one admin to control and manage the warehouse.

\section{Expenditure}

\section{Capital Expenditure}

The equipment price is collected via Tokopedia (e-commerce), while building data is collected in Rumah123.com.

Table 16: Capital Expenditure

\begin{tabular}{llll}
\hline & Price & qty & Total Price \\
\hline *Building & Rp 45.000.000 & 1 & Rp 45.000.000 \\
*Rack (50) & Rp 84.500 & 50 & Rp 4.225.000 \\
Table (3) & Rp 280.000 & 3 & Rp 840.000 \\
Chair (3) & Rp 65.000 & 5 & Rp 325.000 \\
Fan (2) & Rp 174.000 & 2 & Rp 348.000 \\
& & Total & Rp 50.738.000 \\
\hline
\end{tabular}

\section{Operational Expenditure}

On admin wages, the author assumed the wages are similar to labor wages. Hence, the operational expenditure will be wages multiplied by three.

Table 17: Operational Expenditure

\begin{tabular}{llll}
\hline & Wages & qty & Total Cost \\
\hline *Labour Wages & Rp 3.623.779 & 2 & Rp 7.247.558 \\
\hline
\end{tabular}




\begin{tabular}{|c|c|c|c|}
\hline \multirow[t]{2}{*}{ Admin } & Rp 3.623.779 & 1 & Rp 3.623.779 \\
\hline & & Total & Rp 10.871.337 \\
\hline
\end{tabular}

\section{Conclusion}

On answering the research problem, the author conducted discrete-event simulation via application software, Anylogic. The data collected comes from 3 resources, such as primary data (Urbanis internal data), secondary data (online data collection), and observation data (Interview and observation). Then, the data will be analyzed using Anyogic to find how many people and equipment (rack) need by the Urbanis to provide food products in the future. The discrete-event simulation results will be the basis for answering the problem statement of this research. The problem is satiated as follows:

Urbanis need to have a warehouse with a maximum rack dimension of 50 racks while having two labor to work on food produce storing and picking. Looking at rumah123.com, the layout suitable for urbanis is locate in Bandung with a minimum land area requirement of $5 \times 14$ meters. Aside from that, the author acknowledges there is a need for additional equipment not yet analyzed in this research, such as furniture, detailed order picking equipment, table, chair, fan, etc.

It shows that for both the 1st quarter and 2nd quarter warehouse scenario, urbanis need a similar amount of labor, which is two manpower for order picking activities. For the rack, it has differences in both quarters, in the first quarter, with the labor used 2, the maximum racked used will be 32 . Meanwhile, in the second quarter the maximum rack used is 50 .

We found that the building is rent for a minimum yearly based on data collected in Rumah123.com. For this reason, the author suggests finding a suitable building with a maximum rack used in all quarters, 50 racks. Based on rumah123.com, the suitable place (least expensive and could accommodate future projection), will cost the company $\mathrm{Rp} 45.000 .000$ each year.

The author then calculates capital and operational expenditure. The author found that the company's capital expenditure will be Rp 50.738.000 per year, while operational expenses will be Rp 10.871.337 for a month. This expense consists of the variable data analyzed in the simulation (labor and rack) and not analyzed or additional such as fan, chair, table, and admin.

\section{References}

Ashayeri, J. \& Gelders, L. (1985). Warehouse design optimization. European Journal of Operational Research, 21(3), 285-294.

Banks, J. et al. (2014). Discrete-event system simulation, Harlow, Essex: Pearson Education.

Chan, F.T. \& Chan, H. (2011). Improving the productivity of order picking of a manual-pick and multi-level rack distribution warehouse through the implementation of class-based storage. Expert Systems with Applications, 38(3), 2686-2700.

Deelstra, T. \& Girardet, H. (1999). Urban agriculture and sustainable cities, Proc. of the International Workshop "Growing Cities Growing Food", Havana, Cuba. Thematic Paper, 2, 43-65.

Girardet, H. (2008). Cities people planet: urban development and climate change, John Wiley \&amp; Sons.

Hsieh, L.-F. \& Tsai, L. (2005). The optimum design of a warehouse system on order picking efficiency. The International Journal of Advanced Manufacturing Technology, 28(5-6), 626637.

Indonesia Population (LIVE). Retrieved April 26, 2020, from https://www.worldometers.info/worldpopulation/indonesia-population/

Jual rak tv/rak/meja tingkat/meja/meja rak/meja susun 2/meja kayu/furniture - Jakarta Utara - HAGA MAS. (n.d.). Retrieved August 18, 2020, from https://www.tokopedia.com/hagamas/rak-tv-rakmeja-tingkat-meja-meja-rak-meja-susun-2-meja-kayu-furniture 
Liu, T., Yang, M., Han, Z., \& Ow, D. W. (2016). Rooftop production of leafy vegetables can be profitable and less contaminated than farm-grown vegetables. Agronomy for Sustainable Development, 36(3). http://doi.org/10.1007/s13593-016-0378-6

M, S. C. Green roof urban farming for buildings in high-density urban cities. Retrieved from https://www.researchgate.net/publication/228933623_Green_roof_urban_farming_for_buildings in_high-density_urban_cities

Maxwell, D. G. (1995). Alternative food security strategy: A household analysis of urban agriculture in Kampala. World Development, 23(10), 1669-1681. http://doi.org/10.1016/0305750x(95)00073-1

Mincyte, D. \& Dobernig, K. (2016). Urban farming in the North American metropolis: Rethinking work and distance in alternative food networks. Environment and Planning A: Economy and Space, 48(9), 1767-1786. http://doi.org/10.1177/0308518x16651444

Nakamura, H., Kajikawa, Y., Suzuki, S. (2012). Multi-level perspectives with technology readiness measures for aviation innovation. Sustain Sci. 8, 87e101.

Pölling, B., Prados, M.-J., Torquati, B. M., Giacchè, G., Recasens, X., Paffarini, C., ... Lorleberg, W. (2017). Business models in urban farming: A comparative analysis of case studies from Spain, Italy and Germany. Moravian Geographical Reports, 25(3), 166-180. http://doi.org/10.1515/mgr-2017-0015

Thomaier, S., Specht, K., Henckel, D., Dierich, A., Siebert, R., Freisinger, U. B., \& Sawicka, M. (2014). Farming in and on urban buildings: Present practice and specific novelties of ZeroAcreage Farming (ZFarming). Renewable Agriculture and Food Systems, 30(1), 43-54. http://doi.org/10.1017/s1742170514000143

Xiao, Y.-B., Chen, J., \& Xu, X.-L. (2008). Fresh Product Supply Chain Coordination under CIF Business Model with Long Distance Transportation. Systems Engineering - Theory \& Practice, 28(2), 19-34. http://doi.org/10.1016/s1874-8651(09)60009-0 